\title{
GAMBARAN PENGETAHUAN REMAJA PUTRI TENTANG KEPUTIHAN DI KELAS XI SMK NEGERI 1 KOTA TEGAL
}

\author{
Siti Komariyah ${ }^{1}$, Edy Sucipto ${ }^{2}$, Nilatul Izah $^{3}$ \\ Email: izzah_naila@yahoo.co.id \\ ${ }^{123}$ D III Kebidanan Politeknik Harapan Bersama \\ Jln. Mataram No. 09 Tegal \\ Telp./Fax. (0283) 352000
}

\begin{abstract}
Abstrak
Keputihan meskipun termasuk penyakit sederhana, kenyataanya keputihan adalah penyakit yang tidak mudah disembuhkan. Penyakit ini menyerang sekitar 50\% populasi perempuan dan mengenai hampir pada semua umur. Pengetahuan remaja tentang keputihan akan mempengaruhi sikap dan perilaku hidup bersih dan sehat. pengetahuan merupakan domain yang sangat penting terbentuknya tindakan seseorang. Penelitian ini bertujuan untuk mengetahui gambaran pengetahuan remaja putri terhadap keputihan di SMK N 1 Kota Tegal tahun 2015. Pengetahuan adalah hasil dari tahu yang terjadi melalui proses sensoris khususnya mata dan telinga terhadap objek tertentu. Keputihan yaitu cairan putih yang keluar dari liang senggama secara berlebihan. Keputihan merupakan data yang sering ditemukan pada peradangan saluran genetalia wanita.Normalnya, padawaktu ovulasi cairan yang keluar jumlahnya sedikit, encer dan berwarna putih.Jenis penelitian adalah survei deskriptif, desain penelitian yang digunakan observasi dengan pendekatan cross sectional. Populasi dalam penelitian ini remaja putri kelas XISMK Negeri 1 Kota Tegal adalah 273siswa. Teknik sampel yaitu Stratified random sampling pada 73 remaja putri. Data primer didapatkan dari kuesioner. Analisis univariat dengan analisis distribusi frekuensi.

Hasil penelitian menunjukkan bahwa karakteristik remaja putri di SMK Negeri 1 Kota Tegal adaah sebagian besar berumur 15-17 tahun (61,6\%), tingkat ekonomi $\geq$ UMR (74\%) dan status kesehatan sehat (76,7\%). Berpengetahuan cukup tentang keputihan(41,1\%), dimana responden sebagian besar berpengetahuan cukup tentang pengertian keputihan $(52,1 \%)$, dan sebagaian besar berpenegtahuan kurang terhadap tanda dan gejala keputihan(57,5\%), penyebab keputihan(42,5\%), klasifikasi keputihan(50,7\%), perawatan kejadian keputihan $(65,8 \%)$ dan pencegahan kejadian keputihan(67,1\%). Disarankan bagi remaja putri untuk meningkatkan wawasan tentang keputihan serta selalu berperilaku hidup bersih dan sehat dan menjaga kebersihan daerah kewanitaan.
\end{abstract}

Kata Kunci: Pengetahuan, remaja putri, keputihan

\section{Pendahuluan}

Masa remaja merupakan masa transisi antara masa anak-anak ke masa berikutnya, selama masa remaja akan terjadi kecepatan pertumbuhan atau pacu tumbuh (growth sport), dan mulai munculnya seks sekunder pada laki-laki maupun perempuan mulai terjadi fertilitas dan terjadi perubahan psikososial. ${ }^{[1]}$

Keputihan meskipun termasuk penyakit sederhana, kenyataanya keputihan adalah penyakit yang tidak mudah disembuhkan. Penyakit ini menyerang sekitar 50\% populasi perempuan dan mengenai hampir pada semua umur. Data penelitian tentang kesehatan reproduksi wanita menunjukkan
75\% wanita di dunia enderita keputihan paling tidak sekali seumur hidup dan $45 \%$ diantaranya bisa mengalaminya sebanyak dua atau lebih. Kejadian keputihan Di Indonesia mencapai $75 \%$ wanita mengalami keputihan yang disebabkan oleh jamur dan parasit seperti cacing kremi atau protozoa (Trichomonas vaginalis). Angka ini berbeda tajam dengan Eropa yang hanya 25\% saja, karena cuaca di Indonesia yang lembab sehingga mudah terinfeksi jamur Candida albicans yang merupakan salah satu penyebab keputihan. ${ }^{[2]}$

Persoalan yang banyak dihadapi para remaja adalah persoalan kesehaan reproduksi. Kesehatan reproduksi sendiri 
dapat diartikan sebagai suatu kondisi sehat yang bukan saja bebas dari penyakit atau kecacatan, namun sehat baik secara mental maupun social yang berkaitan dengan system, fungsi dari proses reproduksi. ${ }^{[3]}$

Kesehatan reproduksi di kalangan remaja khusunya remaja wanita harus memperoleh perhatian yang serius. Beberapa penyakit-penyakit infeksi organ reproduksi wanita adalah trikomoniasis, vaginosis bakterial, kandidiasis vulvovaginitis, gonore, klamida,sifilis, ulkus motel chancroid. Salah satu gejala dan tanda-tanda penyakit infeksi organ reproduksi wanita adalah terjadinya flour albus (keputihan). Keputihan merupakan salah satu masalah yang sejak lama menjadi persoalan bagi kaum wanita. Fluor Albus (Keputihan) adalah keluarnya sekret atau cairan dari vagina. Sekret tersebut dapat bervariasi dalam konsistensi, warna dan bau. ${ }^{[4]}$

Banyak wanita di Indonesia yang tidak tahu tentang keputihan sehingga mereka menggangap keputihan sebagai hal yang umum dan sepele, di samping itu rasa malu ketika mengalami keputihan kerap membuat wanita enggan berkonsultasi ke dokter. Padahal keputihan tidak bisa di anggap sepele, karena akibat dari keputihan ini sangat fatal bila lambat ditangani tidak hanya bisa mengakibatkan kemandulan dan hamil di luar kandungan, keputihan juga bisa merupakan gejala awal dari kanker leher yang bisa berujung pada kematian. ${ }^{[5]}$

Ada banyak penyebab dari keputihan namun paling sering disebabkan oleh infeksi jamur candida, bakteri parasit seperti trikomonas yang menyebabkan peradangan pada vagina dan sekitarnya. Untuk menghindari komplikasi yang serius dari keputihan, sebaiknya penatalksanaan dilakukan sedini mungkin seperti melalui personal highiene yang baik dan perawatan pada genetalia eksterna. ${ }^{[6]}$

Menjaga kebersihan saat menstruasi merupakan salah satu cara aman untuk mencegah kuman dan infeksi pada vagina yang dapat mengakibatkan penyakit gangguan reproduksi. Hal ini karena keputihan berasal dari organ reproduksi, maka kondisi ini harus ditangani dengan benar dan hati-hati sehingga kebersihan daerah pribadi menjadi hal yang penting. ${ }^{[7]}$

Pengetahuan remaja tentang keputihan akan mempengaruhi sikap dan perilaku hidup bersih dan sehat, karena menurut Notoatmodjo $^{[8]}$, pengetahuan merupakan domain yang sangat penting terbentuknya tindakan seseorang karena dari pengalaman dan penelitian ternyata prilaku dengan didasari oleh pengetahuan akan lebih langgeng daripada prilaku dengan tidak didasari oleh pengetahuan.

Berdasarkan studi pendahuluan yang dilakukan pada bulan Februari 2014 melalui wawancara pada 10 siswi di SMK N 1 Kota Tegal mengenai pengetahuan tentang kesehatan reproduksi remaja terutama keputihan, didapatkan 6 orang (60\%) dalam kategori tidak tahu pencegahan serta mengantisipasi penanganan kejadian keputihan, 4 orang (40\%) tahu dengan baik terhadap pencegahan serta mengantisipasi penanganan kejadian keputihan. Tujuan penelitian ini adalalh untuk mengetahui gambaran pengetahuan remaja putri terhadap keputihan di SMK N 1 Kota Tegal tahun 2015.

\section{Metode Penelitian}

Jenis penelitian yang digunakan adalah survei deskriptif. Rancangan penelitian yang digunakan dalam penelitian ini adalah observasi dengan pendekatan cross sectional yaitu suatu penelitian untuk mempelajari dengan cara pendekatan observasi atau pengumpulan data sekaligus pada suatu saat (point time approach).

Populasi dalam penelitian ini adalah remaja putri kelas XISMK Negeri 1 Kota Tegal adalah 273siswa.Teknik pengambilan sampel dengan menggunakan metode cluster random sampling yang berjumlah 73 siswi. Kriteria inklusi dalam penelitian ini adalah remaja putri kelas XI yang masuk sekolah pada waktu penelitian dan bersedia menjadi responden.

Jenis data yang dikumpulkan dalam penelitian ini adalah primer dan sekunder. Pengumpulan data primer dilakukan dengan cara mengisi kuesioner. Dalam penelitian ini adalah pengetahuan remaja putri terhadap keputihan.Pengumpulan data sekunder berasal dari data kesiswaan. Metode yang 
digunakan untuk mengumpulkan data adalah dengan kuesioner yang berisi tentang item pertanyaan tentang keputihan yang dibagikan kepada responden. Analisa data yang dilakukan adalah analisis univariat, yaitu untuk mengetahui gambaran pengetahuan remaja putri terhadap keputihandengan menggunakan teknik deskriptif dengan prosentase.

\section{Hasil Dan Pembahasan}

a. Karakteristik Responden

1) Umur

Tabel 1.Umur Responden

\begin{tabular}{ccc}
\hline $\begin{array}{c}\text { Umur } \\
\text { (tahun) }\end{array}$ & $\mathrm{F}$ & $\%$ \\
\hline $13-14$ & 0 & 0 \\
$15-17$ & 45 & 61.6 \\
$18-21$ & 28 & 38.4 \\
\hline Total & 73 & 100 \\
\hline
\end{tabular}

Hasil penelitian menunjukkan bahwa sebagian besar responden berumur 15-17 tahun $(61,6 \%)$ dan sisanya berumur 18-21 tahun yaitu $38,4 \%$, umur merupakan proses perjalanan seseorang dalam mengarungi kehidupan, yang dijadikan pelajaran hidup. Pada usia ini remaja untuk mencari jati dirinya dan suka menentang, dimana responden dalam kategori umur yang dapat menerima sesuatu hal yang baru yang lebih baik dan umur yang mudah mencerna informasi menjadi pengetahuan.

Responden yang berumur 18-21 tahun $(38,4 \%)$, responden sudah mempunyai pengalaman dalam menghadapi keadaan kesehatan yang dialaminya. Pengalaman juga dapat dijadikan cara untuk menambah pengetahuan seseorang. Perbedaan usia yang dilakukan ini juga mempengaruhi daya tangkap dan pola berpikir seseorang. Semakin bertambah usia seseorang semakin berkembang pula daya dan pola berpikir seseorang sehingga pengetahuan yang diperoleh semakin baik.

Menurut Hurlock yang dikutip oleh Nursalam ${ }^{[9]}$, bahwa semakin cukup umur, tingkat kematangan dan kekuatan seseorang lebih dipercaya dari orang- orang yang belum cukup tinggi dewasanya.Menurut Taufik $^{[10]}$, mengemukakan bahwa makin tua umur seseorang maka proses-proses perkembangan mentalnya bertambah baik.

Hasil penelitian ini sesuai dengan pendapat Hurlock, bahwa umur mempengaruhi tingkat pengetahuan, hal ini disebabkan dengan umur yang tinggi pada masa produktif keingintahuan tentang pengetahuan khususnya tentang kesehatan reproduksi (keputihan) sehingga responden banyak mencari informasi tentang gangguan kesehatan reproduksi dengan sering membaca dan bertanya pada tenaga kesehatan.

2) Ekonomi Keluarga

Tabel 2. Ekonomi Keluarga Responden

\begin{tabular}{ccc}
\hline Ekonomi & F & $\%$ \\
\hline$<$ UMR & 19 & 26.0 \\
$\geq$ UMR & 54 & 74.0 \\
\hline Total & 73 & 100 \\
\hline
\end{tabular}

Berdasarkan hasil penelitian menunjukkan bahwa sebagian besar penghasilan keluarga responden yaitu lebih besar dari UMR (Rp. 1.206.000) (74\%)artinya berada dalam keluarga yang mempunyai perekonomian yang cukup, dimana dengan kemampuan finansial keluarga yang cukup akan mendorong untuk berkehidupan yang lebih baik sehingga selalu mencari informasi kesehatan.

Adapun responden dengan tingkat ekonomi kelurga kurang sebanyak $26 \%$, hal ini akan mempengaruhi keluarga dalam bidang kesehatan, karena keluarga hanya terfokus pada pemenuhan kebutuhan pokok saja.

Status ekonomi merupakan gambaran tingkat kehidupan seseorang dalam masyarakat yang ditentukan dengan pendapatan keluarga karena ini dapat mempengaruhi aspek kehidupan termasuk pemeliharaan kesehatan dan pengetahuan $^{[8]}$.

Hasil penelitian ini sesuai dengan pendapat Notoatmodjo, bahwa status ekonomi mempengaruhi tingkat pengetahuan, hal ini disebabkan dengan 
status ekonomi keluarga cukup, maka keluarga tidak terfokus pada pemenuhan kebutuhan pokok saja, akan tetapi akan memenuhi kebutuhan yang lain berkaitan dengan kesehatan.

3) Status Kesehatan

Tabel 3. Status Kesehatan Responden

\begin{tabular}{ccc}
\hline Status Kesehatan & F & $\%$ \\
\hline Tidak Sehat & 17 & 23.3 \\
Sehat & 56 & 76.7 \\
\hline Total & 73 & 100
\end{tabular}

Berdasarkan hasil penelitian menunjukkan bahwa sebagian besar kondisi status kesehatan responden adalah berada kondisi sehat yaitu sebanyak 56 responden $(76,7 \%)$, artinya responden tidak mengalmai penyakit kronik, hal ini karena remaja banyak melakukan pola hidup yang sehat seperti olahraga, menjaga kebersihan diri akan tetapi secara pola makan tidak berdasarkan pola makan yang sehat. Responden dengan status kesehatan yang baik, akan memicu untuk dapat memahami tentang informasi yang berkaitan dengan kesehatan dirinya, sehingga akan melakukan perilaku hidup sehat.

Adapun responden yang dalam kondisi tidak sehat $(23,3 \%)$, dimana responden mengalami gangguan keseimbangan, kemampuan agen meningkat misalnya virulensi bertambah atau resistensi bertambah; kepekaan host meningkat misal gizi turun, kecapekan, dan kekebalan tubuh menurun; pergeseran lingkungan yang meningkatkan kemampuan agen misalnya lingkungan kotor, hujan, perubahan lingkungan yang meningkatkan kepekaan host misal kepadatan penduduk, hujan, kemarau. Hal ini akan mempengaruhi kemampuan untuk menyerap informasi sebagai pengetahuan.

Hal ini sesuai dengan pendapatan Yundini ${ }^{[11]}$, perubahan gaya hidup seperti perubahan pola makan menjurus kesajian siap santap yang mengandung banyak lemak, protein dan garam tinggi tetapi rendah serat pangan.Menurut Walgito $^{[12]}$, keadaan masyarakatpun akan memberikan pengaruh tertentu terhadap perkembangan individu, baik itu lingkungan primer yaitu lingkungan sosial dengan adanya hubungan yang erat antara anggota satu dengan satu anggota yang lain maupun lingkungan sosial sekunder yaitu lingkungan sosial yang hubungan anggota satu dengan anggota yang lain agak longgar dengan kata lain kurang atau tidak saling mengenal.

Hasil penelitian ini sesuai dengan pendapat Walgito, bahwa status kesehatan sesorang akan mempengaruhi tingkat pengetahuan, hal ini disebabkan pada jiwa yang sehat terdapat pada badan yang sehat, sehingga pengetahuannya pun bertambah.

b. Tingkat Pengetahuan responden tentang keputihan

Tabel 4. Tingkat Pengetahuan Responden

\begin{tabular}{llc}
\hline $\begin{array}{c}\text { Tingkat } \\
\text { Pengetahuan }\end{array}$ & F & $\%$ \\
\hline Kurang & 28 & 38.4 \\
Cukup & 30 & 41.1 \\
Baik & 15 & 20.5 \\
\hline \multicolumn{1}{c}{ Total } & 73 & 100 \\
\hline
\end{tabular}

Tingkat pengetahuan responden tentang keputihan sebagian besar mempunyai pengetahuan cukup yaitu sebanyak 30 responden $(41,1 \%)$, sedangkan responden yang berpengetahuan kurang sebanyak 28 responden $(38,4 \%)$ dan responden mempunyai pengetahuan baik sebanyak 15 responden $(20,5 \%)$.

Berdasarkan hasil penelitian menunjukkan bahwa sebagian besar responden adalah memiliki pengetahuan cukup $(41,1 \%)$, responden tahu tentang penyakit keputihan yang diperoleh dari kenyataan dengan melihat dan mendengar sendiri baik dari saudara, keluarga maupun tenaga kesehatan, juga melalui alat-alat komunikasi seperti membaca surat kabar, mendengar radio, melihat film atau televisi dan sebagainya serta terhadap yang dialaminya. Hal-hal demikian diterima dengan panca indera untuk kemudian diterima otak dan diolah oleh otak. 
Sehingga akan berdampak pada pengetahuan responden tentang keputihan.

Sebagain besar responden mempunyai pengetahuan yang baik $(20,5 \%)$ tentang keputihan, responden mengetahui tentang penyakit keputihan dari orang terdekat seperti ibu, saudara perempuan dan juga dari teman-temannya. Informasi mengenai keputihan didapatkan siswa dari pelajaran di sekolah, serta mendapatkan informasi dari media massa seperti televisi, internet dan media cetak.

Pengetahuan remaja putri tentang keputihan akan mempengaruhi sikap dan perilaku remaja putri dalam melakukan pencegahan dan pengobatan keputihan, sehingga akan selalu melakukan personal hygient untuk menghindari kejadian keputihan.

Pengetahuan remaja putri tentang keputihan adalah sesuatu modal dasar bagi remaja putri untuk melakukan tindakan pencegahan serta pengobatan atau perawatan dari slour albus. Menurut Notoatmodjo $^{[13]}$, menyatakan bahwa pengetahuan itu merupakan kesiapan atau ketersedian untuk bertindak dan bukan merupakan suatu tindakan atau aktifitas, akan tetapi merupakan suatu predisposisi tindakan atau perilaku.

Masa remaja merupakan masa peralihan dari masa anak-anak ke masa dewasa. Masa ini sering disebut dengan masa pubertas.alat-alat atau organ-organ dalam tubuh manusia sudah berfungsi untuk proses reproduksi atau "berkembang biak", remaja diharapkan dapat menjalankan fungsi reproduksinya dengan tepat oleh karena itu dia harus mengenali organ reproduksinya, fungsi yang akan dijalankan dalam proses reproduksi tersebut tidak dapat dilakukan bila organ-organ reproduksi tidak terawat sejak awal.

Adapun pengetahuan responden yang berpengetahuan kurang tentang keputihan $(38,4 \%)$ disebabkan karena banyak faktor seperti ketidaktahuan, faktor sosial budaya dan masih menganggap keputihan merupakan suatu yang normal bagi wanita, dimana berdasarkan hasil penelitian menunjukkan bahwa responden yang berpengetahuan kurang yaitu pada penyebab keputihan, dimana responden tidak tahu, jika keputihan timbul dapat menyebabkan rasa panas saat kencing, kurang tahu pada penyebab keputihan yaitu stress tidak dapat menyebabkan keputihan, dan kurang tahu pencegahan keputihan seperti keputihan tidak dapat dihindari dengan olah raga yang teratur dan pengobatan keputihan dilakukan untuk membunuh jamur agar tidak tumbuh serta responden kurang tahu bahwa keputihan dapat menyebabkan turunnya kepercayaan diri.

Banyak responden yang masih bingung dengan keputihan, sehingga menanyakan tentang bahaya keputhan.Banyak wanita di Indonesia yang tidak tahu tentang keputihan sehingga mereka menggangap keputihan sebagai hal yang umum dan sepele.Padahal keputihan menurut Januar [5], tidak bisa dianggap sepele karena akibat dari keputihan ini sangat fatal bila lambat ditangani tidak hanya bisa mengakibatkan kemandulan dan hamil di luar kandungan, keputihan juga bisa merupakan gejala awal dari kanker leher yang bisa berujung pada kematian.

Penyebab keputihan yang dialami responden banyak yang tidak tahu, dimana menurut Kinanti ${ }^{[4]}$, ada banyak penyebab dari keputihan namun paling sering disebabkan oleh infeksi jamur candida, bakteri parasit seperti trikomonas yang menyebabkan peradangan pada vagina dan sekitarnya. Untuk menghindari komplikasi yang serius dari keputihan, sebaiknya penatalksanaan dilakukan sedini mungkin seperti melalui personal highiene yang baik dan perawatan pada genetalia eksterna.

Responden banyak yang menanyakan tentang cara pencegahan keputihan, dimana menurut Andiyani ${ }^{[6]}$, menjaga kebersihan saat menstruasi merupakan salah satu cara aman untuk mencegah kuman dan infeksi pada vagina yang dapat mengakibatkan penyakit gangguan reproduksi.Hal ini karena keputihan berasal dari organ reproduksi, maka kondisi ini harus ditangani dengan benar dan hati-hati sehingga kebersihan daerah pribadi menjadi hal yang penting.

Peneliti berpendapat bahwa faktor pengetahuan disini adalah penilaian sejauh mana responden mengetahui tentang keputihan. Diantaranya meliputi ciri khas 
keputihan terutama yang tidak normal, cara pencegahan, kurangnya kebersihan dapat menyebabkan keputihan. Pada penelitian yang dilakukan sebelumnya oleh Amelia ${ }^{[7]}$ tentang gambaran perilaku remaja putri SMA, dari total 188 responden yang memiliki pengetahuan tinggi adalah sebesar 131 responen (69.7\%). Disini menunjukan bahwa hasil penelitian tidak sesuai karena perbedaan usia yang diteliti oleh Amelia dari usia 17-21 tahun. Pengalaman juga dapat dijadikan cara untuk menambah pengetahuan seseorang. Perbedaan usia yang dilakukan ini juga mempengaruhi daya tangkap dan pola berpikir seseorang. Semakin bertambah usia seseorang semakin berkembang pula daya dan pola berpikir seseorang sehingga pengetahuan yang diperoleh semakin baik.

Hasil wawancara dengan penelitian, sebagian besar responden mengatakan pernah mengalami keputihan. Keputihan yang mereka alami rata- rata sebelum dan sesudah haid, dimana responden mengalami dari genetalia keluar cairan encer atau kental yang berwarna putih susu, tidak setiap hari dan terjadi setelah atau sebelum menstruasi atau ada mengalami pada saat merasa lelah. Hal ini dikarenakan terjadi peradangan saluran genetalia wanita. Semua responden mengetahui keadaan dirinya mengalami keputihan, dimana responden berdasarkan observasi peneliti dengan wawancara, keputihan dianggap sesuatu yang wajar, karena jika responden mengalami keputihan dan diberikan obat, kemudian pada bulan berikutnya akan mengalami yang sama.

Pengetahuan merupakan hasil dari tahu, dan hal ini terjadi setelah orang melakukan penginderaan terhadap suatu obyek tertentu dalam membentuk tindakan seseorang suatu objek tertentu melalui panca indera manusia yaitu indera penglihatan, pendengaran, penciuman rasa dan $\mathrm{raba}^{[7]}$.

Selain itu, pengetahuan dapat juga diperoleh dari kenyataan dengan melihat dan mendengar sendiri melalui alat-alat komunikasi seperti membaca surat kabar, mendengar radio, melihat film atau televisi dan sebagainya. Hal-hal demikian diterima dengan panca indera untuk kemudian diterima otak dan diolah oleh otak ${ }^{[14]}$.
Hasil penelitian ini sesuai dengan pendapat Notoatmodjo dan Soekanto, yang menyatakan bahwa pengetahuan seseorang dapat diperoleh memalui mendengar, membaca baik dari buku, majalah, surat kabar, internet, mendengar radio, melihat film atau televisi dan sebagainya, hal ini dapat mempengaruhi pengetahuan remaja tentang keputihan

c. Tingkat pengetahuan remaja putri tentang pengertian keputihan

Tabel 5. Pengetahuan tentang pengertian keputihan

\begin{tabular}{ccc}
\hline Tingkat Pengetahuan & F & $\%$ \\
\hline Kurang & 29 & 39.7 \\
Cukup & 38 & 52.1 \\
Baik & 6 & 8.2 \\
\hline Total & 73 & 100 \\
\hline
\end{tabular}

Hasil penelitian menunjukkan bahwa pengetahuan responden tentang pengertian keputihan sebagian besar cukup $(52,1 \%)$. Kebanyakan responden berpengetahuan bahwa keputihan merupakan cairan yang keluar dari vagina yang bukan darah, yang berwarna bening atau putih dan dapat menimbulkan rasa gatal serta mengganggu kenyamanan.Banyak responden yang tidak tahu tentang datangnya keputihan, remaja mengira keputihan adalah cairan yang keluar bersamaan dengan mentruasi yang menimbulkan bau tidak enak. Serta menjawab salah tetang pengertian keputihan adalah semacam slim yang keluar terlalu banyak, warnanya putih seperti sagu kental dan agak kekuning-kuningan.

Responden yang mempunyai pengetahua baik $(8,2 \%)$, dimaa responden tahu tentang pengertian keputihan secara benar. Pengetahuan tentang pengertian keputihan sangat penting sebagai gambaran tentang nama sebuah penyakit dengan definisi penyakit tersebut.

Adapun responden dengan pengetahuan yang kurang $(39,7 \%)$, banyak remaja putri yang menjawab dengan salah tentang definisi keputihan. Hal ini dikarena usiaresponden yang termasuk pada usia remaja tengah, sehingga diperlukan pengetahhuan kesehatan reproduksi untuk remaja putri. 
Keputihan merupakan pengeluaran cairan pervaginam yang tidak berupa darah yang kadang merupakan sebuah manifestasi klinik dari infeksi yang selalu membasahi dan menimbulkan iritasi, rasa gatal dan gangguan rasa aman pada penderitanya. ${ }^{[3]}$

Keputihan merupakan keluarnya cairan encer atau kental dan kekuningan dari lubang vagina disebut keputihan.Bentuk cairan yang keluar menentukan apakah keadaan tersebut berbahaya atau tidak. Namun bila cairan itu bentuknya kental, berwarna putih susu, kuning atau kehijauan, menandakan kehadiran infeksi jamur bakteri yang segera dibasmi ${ }^{[15]}$

d. Tingkat pengetahuan remaja putri tentang tanda dan gejala keputihan

Tabel 6.Pengetahuan tentang tanda dan gejala keputihan

\begin{tabular}{ccc}
\hline Tingkat Pengetahuan & F & $\%$ \\
\hline Kurang & 42 & 57.5 \\
Cukup & 29 & 39.7 \\
Baik & 2 & 2.7 \\
\hline Total & 73 & 100 \\
\hline
\end{tabular}

Hasil penelitian menunjukkan bahwa pengetahuan responden tentang tanda dan gejala keputihan sebagian besar kurang $(57,5 \%)$. Responden tidak tahu tetang tanda dan gejala keputihan ada rasa gatal, ruam kulit dan nyeri serta keputihan timbul dapat menyebabkan rasa panas saat kencing.

Responden yang berpengetahuan cukup $(39,7 \%)$, dimana responden responden tahu tentang tanda dan gejala keputihan, dimana sebagian responden tahu bahwa keputihan berwarna putih kerabu-abuan atau kuning dengan bau yang menusuk serta keluar disertai rasa gatal, ruam kulit dan nyeri, dengan bergitu remaja putri tidak dapat segera mengenali keputihan sejak dini. Tingkat Pengetahuan tentang tanda dan gejala keputihan dengan kategori baik hanya $2,7 \%$, dimana responden tahu tentang tanda dan gejala keputihan baik keputihan normal maupun keputihan patologis.

e. Tingkat pengetahuan remaja putri tentang penyebab keputihan
Tabel 7.Pengetahuan tentang penyebab keputihan

\begin{tabular}{ccc}
\hline Tingkat & & \\
Pengetahuan & $\mathrm{F}$ & $\%$ \\
\hline Kurang & 31 & 42.5 \\
Cukup & 30 & 41.1 \\
Baik & 12 & 16.4 \\
\hline Total & 73 & 100 \\
\hline
\end{tabular}

Hasil penelitian menunjukkan bahwa pengetahuan responden tentang penyebab keputihan sebagian besar kurang (42,5\%). Responden tidak tahu bahwa stress tidak dapat menyebabkan keputihan dan keputihan dapat disebabkan karena siklus menstruasi, yaitu pada waktu mau menstruasi atau setelah menstruasi.

Responden yang mengetahui tentang penyebab keputihan dengan kategori cukup yaitu sebesar $41,1 \%$ dan dengan kategori baik ada $16,4 \%$. Kebanyakan responden berpengetahuan bahwa keputihan karena bakteri atau juga disebabkan karena infeksi, hal ini akan berdampak pengetahuan dan perilaku untuk melakukan pencegahan kejadian keputihanyaitu melakukan tindakan personal hygient.

Terjadinya keputihan pada vagina wanita dewasa terdapat bakteri yang baik disebut dengan basil doderlein.Dalam keadaan normal jumlah basil ini cukup dominant dan membuat lingkungan vagina bersifat asam sehingga vagina mempunyai daya proteksi yang cukup kuat.Meskipun demikian vagina juga mengeluarkan sejumlah cairan yang berguna untuk melindungi diri dari infeksi. ${ }^{[16]}$

f. Tingkat pengetahuan remaja putri tentang klasifikasi keputihan

Tabel 8. Pengetahuan tentang klasifikasi keputihan

\begin{tabular}{ccc}
\hline Tingkat Pengetahuan & F & $\%$ \\
\hline Kurang & 37 & 50.7 \\
Cukup & 29 & 39.7 \\
Baik & 7 & 9.6 \\
\hline Total & 73 & 100 \\
\hline
\end{tabular}

Hasil penelitian menunjukkan bahwa pengetahuan responden tentang klasifikasi keputihansebagian besar kurang $(50,7 \%)$. Responden tidak tahu bahwa keputihan dapat menyebabkan turunnya kepercayaan diri serta keputihan yang tidak diobati dapat 
menyebab kanker leher rahim.Kebanyakan responden berpengetahuan bahwa keputihan hanya keputihan yang normal dan dikarenakan infeksi vaginal, kanker dan keganasan alat kelamin. Banyaknya responden yang tidak tahu tentang klasifikasi keputihan $(50,7 \%)$, berdampak pada salahnya penanganan keputihan, karena keputihan patologis harus ditangani dengan berkonsultasi pada tenaga kesehatan dan segera diobati secara tepat agar tidak mengalami keputihan yang berulang.

Tingkat pengetahuan tentang klasifikasi keputihan dalam kategori cukup mencapai $39,7 \%$ dan berpengetahuan baik sebanyak $9,6 \%$. Hasil ini menunjukkan bahwa hanya sedikit yang mengetahui klasifikasi keputihan, dimana keputihan terbagi atas dua kategori yaitu keputihan fisiologis atau keputihan normal dan keputihan patologis atau keputihan abnormal.

Keputihan dibagi menjadi 2 bagian yaitu keputihan fisiologis.Dalam keadaan normal ada sejumlah secret yang mempertahankan kelembaban vagina yang mengandung banyak epitel dan sedikit leukosit dengan warna jernih.Tanda-tanda Keputihan normal adalah jika cairan yang keluar tidak terlalu kental, jernih, warna putih atau kekuningan jika terkontaminasi oleh udara, tidak disertai rasa nyeri, dan tidak timbul rasa gatal yang berlebih.Adapun pada keputihan patologis cairan yang keluar mengandung banyak leukosit. Tanda-tanda Keputihan patologis antara lain cairan yang keluar sangat kental dan berubah warna, bau yang menyengat, jumlahnya yang berlebih dan menyebabkan rasa gatal, nyeri, serta rasa sakit dan panas saat berkemih. Faktor-faktor yang menyebabkan Keputihan patologis antara lain infeksi vaginal yang disebabkan oleh kuman, jamur, virus, dan parasit serta tumor, iritasi, fistula, radiasi, kanker dan keganasan alat kelamin juga dapat menyebabkan terjadinya Keputihan. ${ }^{[17]}$

g. Tingkat pengetahuan remaja putri tentang perawatan keputihan
Tabel 9. Pengetahuan tentang perawatan

\begin{tabular}{ccc} 
keputihan & & \\
\hline Tingkat Pengetahuan & F & $\%$ \\
\hline Kurang & 48 & 65.8 \\
Cukup & 12 & 16.4 \\
Baik & 13 & 17.8 \\
\hline Total & 73 & 100 \\
\hline
\end{tabular}

Hasil penelitian menunjukkan bahwa pengetahuan responden tentang perawatan keputihan sebagian besar kurang $(65,8 \%)$. Responden kurang tahu bahwa cara pencegahan keputihan adalah menjaga kebersihan pada organ kemaluan seperti membersihkan dan mengeringkan daerah kemaluan setelah buang air kecil atau besar dengan benar dan keputihan juga dapat dicegah dengan tidak memakai celana dalam yang terbuat dari bahan katun, menghindari pemakaian celana dalam yang sangat ketat dan juga celana jeans yang ketat.

Tingkat pengetahuan tentang perawatan keputihan dalam kategori cukup $(16,4 \%)$ dan kategori baik (17,8\%), hal ini responden sudah tahu tenang pencegahan keputihan seperti menjaga kebersihan pada organ kemaluan seperti membersihkan dan mengeringkan daerah kemaluan setelah buang air kecil atau besar dengan benar.

Untuk menghindari komplikasi yang serius dari keputihan,sebaiknya penatalaksanaan dilakukan sedini mungkin sekaligus untuk menyingkirkan kemungkinan adanya penyebab lain seperti kanker leher rahim yang juga memberikan gejala keputihan berupa sekret encer, berwarna merah muda, coklat mengandung darah atau hitam serta berbau busuk ${ }^{[18]}$.

h. Tingkat pengetahuan remaja putri tentang pencegahan kejadian keputihan

Tabel 10. Pengetahuan tentang pencegahan kejadian keputihan

\begin{tabular}{ccc}
\hline Tingkat Pengetahuan & F & $\%$ \\
\hline Kurang & 49 & 67.1 \\
Cukup & 2 & 2.7 \\
Baik & 22 & 30.1 \\
\hline Total & 73 & 100 \\
\hline
\end{tabular}

Hasil penelitian menunjukkan bahwa pengetahuan responden tentang pencegahan keputihan sebagian besar kurang $(67,1 \%)$. Responden kurang tahu tentang keputihan tidak dapat dihindari dengan olah raga yang 
teratur, dan pengobatan keputihan dilakukan untuk membunuh jamur agar tidak tumbuh.

Responden yang berpengetahuan baik sebanyak $30,1 \%$ dan yang berpengetahuan cukup ada 2,7\%. Kebanyakan responden tahu pencegahan keputihan, dimana keputihan dapat dicegah dengan menjaga kebersihan daerah kelamin, pola hidup sehat dan tidak melakukan prilaku seks pra nikah.

Bila ingin terhindar dari keputihan, yaitu dengan menjaga kebersihan daerah sensitif. Kebersihan organ kewanitaan hendaknya sejak bangun tidur dan mandi pagi. ${ }^{[19]}$

Pengetahuan dapat diperoleh melalui pendidikan pengalaman diri sendiri maupun pengalaman orang lain, media massa maupun lingkungannya. ${ }^{[13]}$

\section{Kesimpulan}

Karakteristik remaja putri di SMK Negeri 1 Kota Tegal adaah sebagian besar berumur 15-17 tahun (61,6\%), tingkat ekonomi $\geq$ UMR (74\%) dan status kesehatan sehat (76,7\%). Pengetahuan remaja putri tentang keputihansebagian besar cukup $(41,1 \%)$ dengan rincian pengetahuantentang pengertian keputihansebagian besar cukup $(52,1 \%)$, tanda dan gejala keputihansebagian besar kurang (57,5\%), penyebab keputihansebagian besar kurang (42,5\%), klasifikasi keputihansebagian besar kurang (50,7\%), perawatan kejadian keputihansebagian besar kurang $(65,8 \%)$, pencegahan kejadian keputihansebagian besar kurang $(67,1 \%)$.

\section{Daftar Pustaka}

[1] Waryono. 2010. Gizi Reproduksi. Yogyakarta : Pustaka Rihama.

[2] Donatila, 2011. Hubungan Antara Pengetahuan Dan PerilakuMenjaga Kebersihan Genitalia Eksterna DenganKejadian Keputihan Pada Siswi Sma Negeri 4Semarang. Skripsi S1 Kedokteran Undip

[3] Manuaba. 2009. Kapita Selekta Penatalaksanaan Rutin Obstetri Genetologi, Kedokteran EGC. Jakarta.

[4] Kinanti S, 2009. She,at Untuk Wanita. Yogyakarta: Nuha Medika.
[5] Januar. 2007.Kesehatan Reproduksi. Jakarta: EGC.

[6] Andiyani, 2011. Pahami Kewanitaan. Jakarta: Gunung Agung

[7] Notoatmodjo. 2007. Ilmu Kesehatan Masyarakat, Jakarta: Rineka Cipta.

[8] Nursalam. 2005. Konsep \& Penerapan Metodologi Penelitian Ilmu Keperawatan : Pedoman Skrips, Tesis dan Instrumen Penelitian. Jakarta: Salemba

[9] Taufik, 2007.Prinsip-Prinsip Promosi Kesehatan Dalam Bidang Keperawatan. CV. Infomedika: Jakarta

[10] Yundini. 2004. Faktor Resiko dan Pengendalian Penyakit Tidak Menular, PT. Gramedia, Jakarta.

[11] Walgito. 2004. Pengantar psikologi Umum. Jakarta: Penerbit Andi.

[12] Amelia. 2009. Faktor yang Berkaitan dengan Kesertaan KB IUD di Kecamatan Balapulang Tegal. Universitas Muhammadiyah Surakarta: Skripsi

[13] Notoatmodjo, S. 2010. Metodologi Penelitian. Jakarta: Rineka Cipta.

[14] Soekanto, 2005. Sosiologi suara pengantar,Jakarta: Raja Grafindo

[15] Dwikarya, 2005. Menjaga Organ Intim, Penyakit dan Penanggulangannya. Jakarta: Kawan Pustaka

[16] Ning Harmanto. 2006. Ibu Sehat dan cantik dengan Herbal. Jakarta: Elek Media Komputindo.

[17] Wiknjosastro. 2007. Ilmu Kandungan. Jakarta: Yayasan Bina Pustaka Sarwono Prawirodihardjo.

[18] Nuraeni. 2006. Faktor Resiko Kejadian Kandidiasis vaginalis pada akseptor KB. Fakultas Kesehatan Masyarakat. Surabaya: UNAIR.

[19] Wijayanti. 2009. Faktor Sosial Budaya dan Pelayanan Kontrasepsi yang Berkaitan dengan Kesertaan KB IUD di Kecamatan Gembong Kabupaten Kebumen. Universitas Muhammadiyah Surakarta: Skripsi 